\title{
LEATHER AS A POTENTIAL LINER FOR THE PROSTHETIC LEG USERS
}

\author{
Arife Candaș ADIGÜZEL ZENGIN*, Nilay ÖRK, Ümitcan YIĞIT, Behzat Oral BITLISLI \\ Ege University, Engineering Faculty, Leather Engineering Department, 35100, Bornova, Izmir, Turkey,
} candas.adiguzel@ege.edu.tr

Received: 01.11.2018

Accepted: 14.12 .2018

https://doi.org/10.24264/Ifj.18.4.7

\section{LEATHER AS A POTENTIAL LINER FOR THE PROSTHETIC LEG USERS}

ABSTRACT. Wear comfort and hygiene is responsible for the significant improvement in the life quality of many amputees and in this regard liners have an important role for the prosthetic leg users. They are protective materials used as covers and worn over the residual limb before the socket to prevent the discomfort occurred during the movements of the patients. Liners are made of different synthetic flexible materials and designed with specific features for different suspension systems. Selecting a correct liner depends on the activity level and needs of the users in addition to the suspension system of the prosthetic leg. Although liners ensure wearing comfort to the users, feeling uncomfortable occurs due to perspiration and lack of evaporation. In this context, leather has advantages due to its triple helix collagen fibers and seems to be a perfect alternative natural material to synthetic liners. For this purpose, the production of a leather liner as an alternative to synthetic liners was aimed to perform for the prosthetic leg users. Chromium free leathers were manufactured based on the properties of the synthetic liners found in the market and the physical, mechanical and comfort properties of the liners in terms of water vapor permeability, static water absorption, tensile strength, elongation at break, tear strength, rubbing fastness and thickness were determined. The results revealed that leather could be used as an alternative natural liner for the use of prosthetic legs and has become prominent due to its wear comfort, hygiene and mechanical properties.

KEY WORDS: leather, prosthesis, liner

\section{PIELEA CA POTENTIIALĂ CĂPTUȘEALĂ PENTRU PROTEZE}

REZUMAT. Confortul în purtare și igiena sunt responsabile pentru îmbunătățirea semnificativă a calității vieții multor persoane cărora li s-au amputat membre și, în acest sens, căptușelile au un rol important pentru utilizatorii de proteze. Acestea sunt materiale de protecție folosite ca înveliș și purtate peste membrul rezidual înainte de a pune proteza pentru a preveni disconfortul care apare în timpul mișcării pacienților. Căptușeala este fabricată din diferite materiale sintetice flexibile și proiectate cu caracteristici specifice pentru diferite sisteme de suspensie. Selectarea unei căptușeli corecte depinde de nivelul de activitate și de nevoile utilizatorilor, pe lângă sistemul de suspensie al piciorului protetic. Deși căptușeala asigură confortul purtătorilor, senzația de disconfort apare din cauza transpirației și a lipsei de evaporare a acesteia. În acest context, pielea are avantaje datorită fibrelor de colagen cu structură de triplu helix și, fiind un material natural, este o alternativă perfectă pentru căptușelile sintetice. În acest scop, s-a propus căptușeala din piele ca alternativă la căptușelile sintetice, funcțională pentru utilizatorii de proteze. Pieile fără crom s-au fabricat pe baza proprietăților căptușelilor sintetice găsite pe piață și s-au determinat proprietățile fizice, mecanice și de confort ale căptușelilor în ceea ce privește permeabilitatea vaporilor de apă, absorbția statică a apei, rezistența la tracțiune, alungirea la rupere, rezistența la sfâșiere, rezistența la frecare și grosimea. Rezultatele au arătat că pielea poate fi utilizată pentru căptușeli naturale alternative utilizate în proteze și este importantă datorită confortului în purtare, igienei și proprietăților sale mecanice. CUVINTE CHEIE: piele, proteză, căptușeală

\section{LE CUIR COMME DOUBLURE POTENTIELLE POUR LES PROTHÈSES}

RÉSUMÉ. Le confort et l'hygiène sont responsables de l'amélioration significative de la qualité de vie de nombreuses personnes amputées d'un membre, à cet égard, les doublures ont un rôle important à jouer pour les utilisateurs de prothèses. Ce sont des matériaux de protection utilisés comme couvertures et portés sur le membre résiduel avant la pose de la prothèse pour éviter l'inconfort survenu lors des mouvements des patients. Les doublures sont fabriqués à partir de différents matériaux synthétiques flexibles et conçues avec des caractéristiques spécifiques pour différents systèmes de suspension. Le choix d'une doublure appropriée dépend du niveau d'activité et des besoins des utilisateurs, en plus du système de suspension de la jambe prothétique. Bien que les doublures assurent le confort des utilisateurs, le sentiment de malaise survient en raison de la transpiration et du manque d'évaporation. Dans ce contexte, le cuir présente des avantages en raison de ses fibres de collagène à triple hélice et semble constituer un matériau de remplacement naturel idéal pour les doublures synthétiques. À cette fin, la production d'une doublure en cuir en tant qu'alternative aux doublures synthétiques a été destinée aux utilisateurs de prothèses. Des cuirs sans chrome ont été fabriqués sur la base des propriétés des doublures synthétiques disponibles sur le marché, et on a déterminé leurs propriétés physiques, mécaniques et de confort, la perméabilité à la vapeur d'eau, l'absorption statique d'eau, la résistance à la traction, l'allongement à la rupture, la résistance au déchirement, la résistance au frottement et l'épaisseur. Les résultats ont révélé que le cuir pourrait être utilisé comme une doublure naturelle alternative utilisée dans les prothèses et il est devenu une priorité en raison de son confort, de ses propriétés hygiéniques et mécaniques.

MOTS CLÉS : cuir, prothèse, doublure

\footnotetext{
* Correspondence to: Arife Candaș ADIGUZEL ZENGIN,Ege University, Engineering Faculty, Leather Engineering Department,Bornova, izmir, candas.adiguzel@ege.edu.tr
} 


\section{INTRODUCTION}

The lack of prostheses comfort occurred due to the heat and perspiration are the main problems of the amputee people and till now no correlation has been found with the prosthesis type, amputation cause, and amputated limb [1-3]. The heat inside the prosthetic socket leads to perspiration and many complaints have arisen about health, discomfort, odor as well as the use of prostheses [3]. Up to now, aesthetic and biomechanical properties of the prostheses have the major attention and prostheses are produced without taking into consideration the heat, perspiration, discomfort and cold stress problems [3, 4]. In recent years, a liner company has introduced a new type of liner with a phase change material as a potential solution for heat and perspiration discomfort $[3,5]$ and a prototype with air-based helical cooling channel is designed for the prosthetic socket [6]. Besides, Ghoseiri et al., 2016, have studied the prototype of a thermoregulatory system for measurement and control of temperature inside prosthetic socket as well as the evaluation of the prototype functionally $[3,7]$. However, further studies are needed to confirm the efficiency of the systems to resolve the discomfort complaints of the users [5], although measuring and quantifying the comfort is difficult [1].

Liners are covers worn over the residual limb before the prosthetic sockets and have an important role in terms of wear comfort and hygiene. They are produced by different synthetic materials such as silicone, polyurethane and copolymer and designed for different suspension systems. Although liners ensure wearing comfort to the users, discomfort occurs due to the perspiration and lack of evaporation. Although there are some studies on resolving the thermal discomfort [3-7], no study has been published about manufacturing a leather liner for the amputees. From the point of wear comfort and hygiene, leather has advantages due to its triple helix collagen fibers and seems to be a perfect alternative natural material to synthetic liners.
In this study, the manufacturing of a leather liner as an alternative to synthetic liners was aimed for the prosthetic leg users. Chromium free leathers were manufactured based on the properties of the synthetic liners (gel and silicone based) found in the market and the performance properties in terms of water vapor permeability, static water absorption, tensile strength, elongation at break, tear strength, rubbing fastness and thickness were determined.

\section{EXPERIMENTAL}

\section{Materials}

The synthetic commercial liners based on gel and silicone material were obtained from Deva Orthopedics in Izmir, Turkey. Gel (2 with socks and 1 without sock) and silicone liners were used in the study to compare the physical, mechanical and comfort properties with the produced chromium free leathers.

In the study, four pickled domestic sheepskins were used for the chromium-free tanning procedure. Zirconium and aluminum were used as the main tanning materials and the conventional leather chemicals were used in the production processes. The pickled sheep skins used in tanning trials were supplied from Güvener Company in Izmir, Turkey.

\section{Methods}

\section{Tanning Procedure}

Depickling, bating and degreasing processes were performed to pickled sheepskins with conventional formulation and the pelts were tanned with $4 \%$ zirconium and $4 \%$ aluminum over skin weight. After the tanning process, leathers were converted into crust leathers by retanning and fatliquoring processes, using synthetic sulphited and combination fatliqours. No finishing application was performed and the recipe of the leather manufacturing is given in Table 1.

Table 1: Tanning procedure of the chromium free leathers

\begin{tabular}{|c|c|c|c|c|c|}
\hline Process & Amount (\%) & Product & Temp $\left({ }^{\circ} \mathrm{C}\right)$ & Time(Min.) & $\mathrm{pH}$ \\
\hline Depickle & $\begin{array}{c}150 \\
2\end{array}$ & $\begin{array}{c}\text { Water } 6^{\circ} \mathrm{Be} \\
\mathrm{HCOONa}\end{array}$ & $28-30$ & $\begin{array}{c}10 \\
30(15 * 2)\end{array}$ & 45 \\
\hline Bating & $\begin{array}{c}1 \\
100\end{array}$ & Water & 35 & & \\
\hline
\end{tabular}




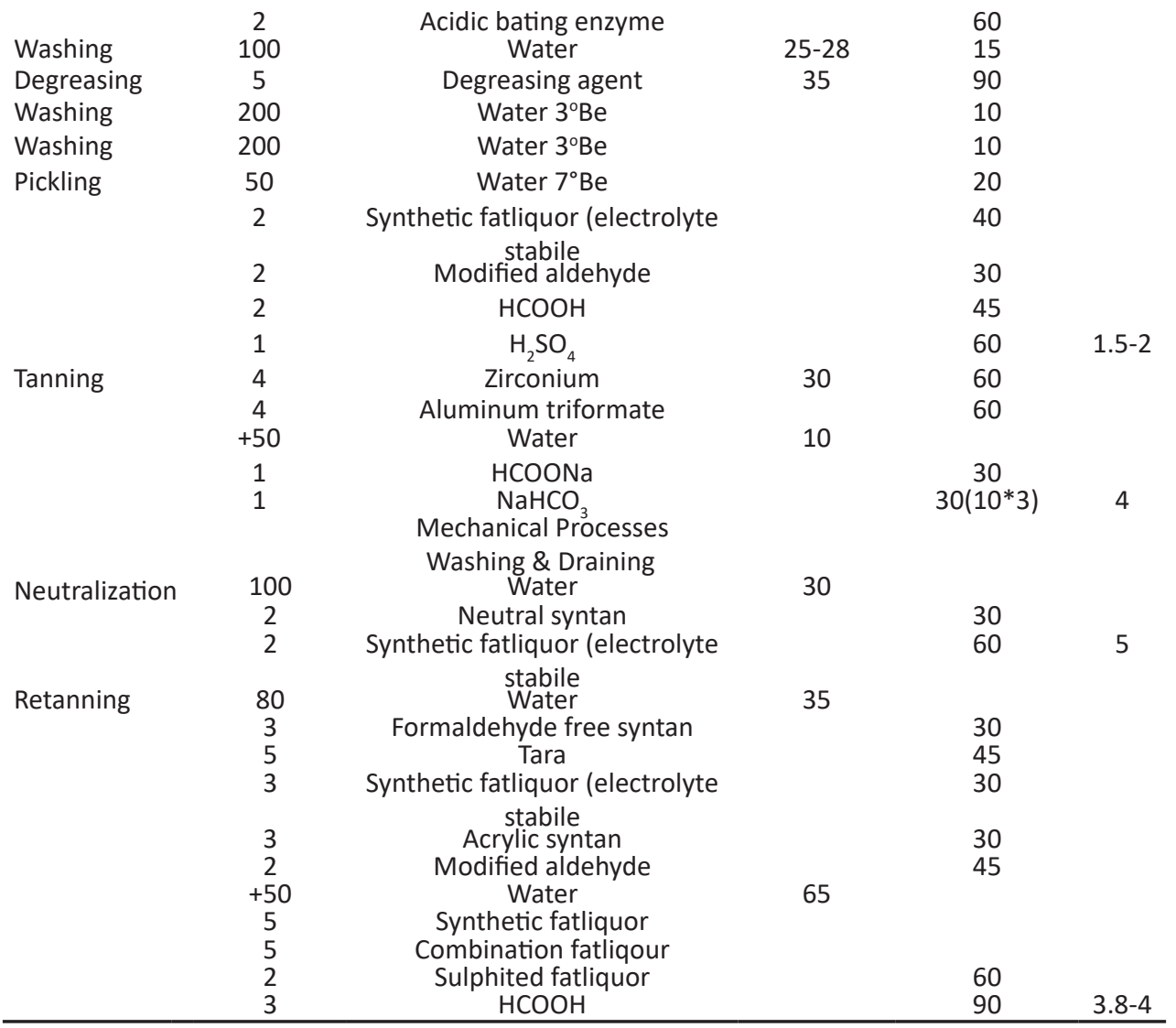

Later, the half of the chromium-free crust leathers was laminated with spandex fabric to increase the elasticity of the crust leathers for the use in prosthetic legs as a liner [8].

\section{Determination of Physical, Mechanical and Comfort Properties of the Liners}

The physical, mechanical and comfort properties of the synthetic and leather liners were determined in order to compare the properties of the liners and to produce an alternative leather liner for the prosthetic legs.

Subsequent to sampling of the synthetic liners and leathers (TS EN ISO 2418), the samples were conditioned at $23 \pm 2^{\circ} \mathrm{C}$ and $50 \pm 5 \%$ relative humidity for $48 \mathrm{~h}$ in accordance with the standard of TS EN ISO 2419 prior to the tests [9, 10].

The comfort properties of the liners were determined in terms of water vapor permeability and static water absorption in accordance with the standards of TS EN ISO 14268 (2004) and TS 4123 EN ISO 2417 (2005) respectively [11, 12].

Mechanical resistance of the liners were investigated by performing the tests of tensile strength, and elongation at break (TS EN ISO 3376) and tear strength (TS EN ISO 3377-2) with reference to standard methods respectively [13,
14].

The thickness of the samples was determined with SATRA Thickness Gauge with the standard of TS EN ISO 2589 [15].

The rubbing fastness properties of the samples were examined with a Bally Finish Tester 9029 according to TS EN ISO 11640 standard (100 rubs dry and 25 rubs wet) [16]. The tests were done in duplicates and the results were given as mean values and the standard deviations.

\section{RESULTS AND DISCUSSIONS}

The physical, mechanical and comfort properties of the gel, silicone and leather liners were determined and comparatively evaluated.

The thickness values of the gel, silicone and leather liners are given in Figure 1. Crust chromium free leathers were found the thinnest material compared to other liners including stretched leathers. By the lamination of the leather with spandex fabric, an increase was found in thickness values, however the leather liners were found still thinner than the commercial liners (Figure 1). The thickness values of the gel liners were determined between 5.9 and $6.1 \mathrm{~mm}$ due to the incorporation of the cotton material. To have a high thickness value 
seems to have an advantage because thick and soft materials could help to prevent the feeling of discomfort occurred during the movements of the prosthetic leg users.

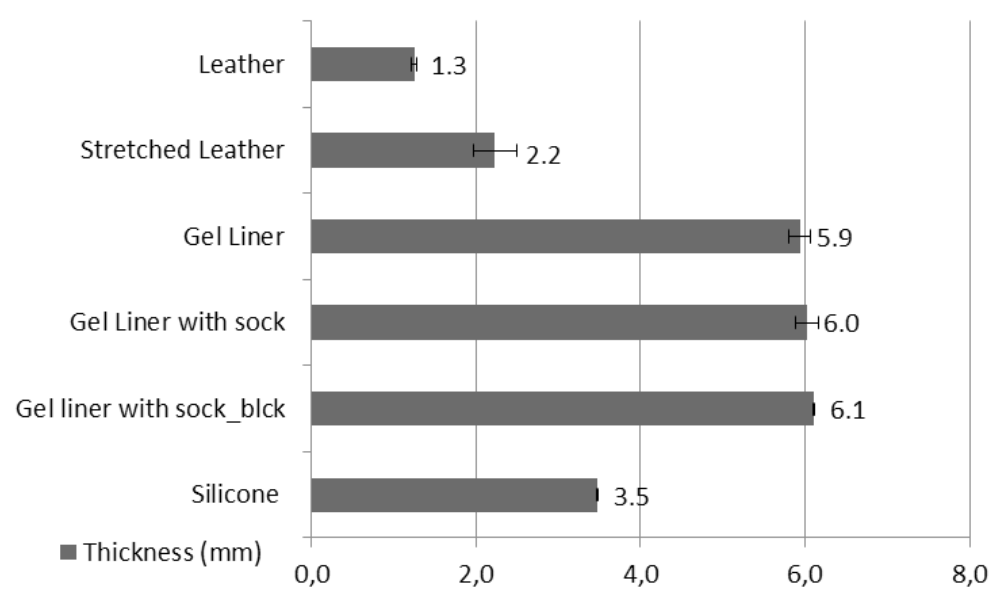

Figure 1. Thickness results of the liners

\section{Comfort Properties of the Liners}

Silicone based liner had the lowest water vapor permeability with the result of $0.08 \pm 0.01$ $\mathrm{mg} / \mathrm{cm}^{2} \mathrm{~h}$. Gel liners with socks had higher results compared to silicone, however lower results were obtained in comparison to gel and leather liners. The highest result was determined from the gel liner among the common used synthetic liners. However, it does not seem sufficient from the point of wear comfort and hygiene due to the complaints of the patients [3-7]. The natural character of the leather, also in the form of with and without stretched, provides a considerably high water vapor permeability compared to gel and silicone liners and leather could be manufactured in the view of the required qualifications from the liners and be used as an alternative natural liner (Figure 2).

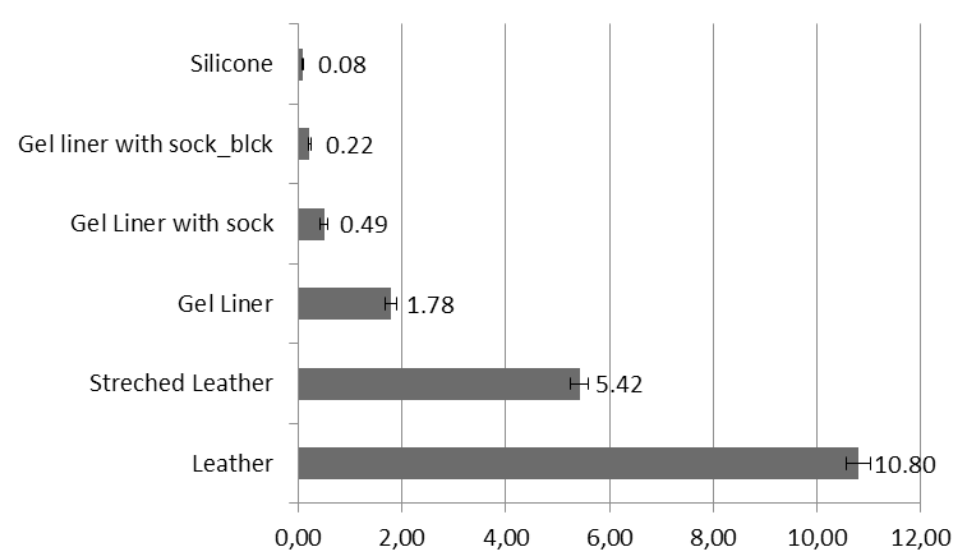

Figure 2. Water vapour permeability results of the liners

The static water absorption (Kubelka) test results at six different time interval are shown in Table 2. In contrast to the results of water vapor permeability, the minimum water uptake was determined from the gel liner and the increase in water uptake was due to the cottons that incorporated to the gel liners. Although silicone based liner had very low water vapor permeability, the water uptake capacity was found higher than the gel liners. The different Kubelka results of the leathers were due to the lamination of spandex fabric on the suede side of the chromium free leathers. This spandex fabric prevented the water uptake into the leather and resulted $10 \%$ decrease in water absorption results of the stretched leathers (Table 2 ). 
Table 2: Static water absorption results of the liners

\begin{tabular}{|c|c|c|c|c|c|c|}
\hline & $1 / 12 \mathrm{~h}$ & $1 / 4 h$ & $1 / 2 \mathrm{~h}$ & $1 \mathrm{~h}$ & $2 \mathrm{~h}$ & $24 h$ \\
\hline $\begin{array}{l}\text { Silicone } \\
\text { Gel liner with sock_ }\end{array}$ & $\begin{array}{c}16.17 \pm 0.16 \\
4.49 \pm 1.27\end{array}$ & $\begin{array}{c}30.74 \pm 2.60 \\
4.49 \pm 1.27\end{array}$ & $\begin{array}{c}33.95 \pm 1.94 \\
4.49 \pm 1.27\end{array}$ & $\begin{array}{c}35.57 \pm 0.36 \\
4.49 \pm 1.27\end{array}$ & $\begin{array}{c}37.18 \pm 1.91 \\
6.29 \pm 1.27\end{array}$ & $\begin{array}{c}46.83 \pm 1.81 \\
8.98 \pm 2.54\end{array}$ \\
\hline $\begin{array}{l}\text { blck } \\
\text { Gel Liner with sock } \\
\text { Gel Liner } \\
\text { Stretched Leather } \\
\text { Leather }\end{array}$ & $\begin{array}{c}10.95 \pm 1.43 \\
0 \pm 0 \\
154.21 \pm 29.32 \\
177.89 \pm 31.58\end{array}$ & $\begin{array}{c}12.94 \pm 1.44 \\
0 \pm 0 \\
161.93 \pm 32.15 \\
181.82 \pm 37.13\end{array}$ & $\begin{array}{c}12.94 \pm 1.44 \\
0 \pm 0 \\
166.01 \pm 29.82 \\
189.28 \pm 37.68\end{array}$ & $\begin{array}{c}12.94 \pm 1.44 \\
1.78 \pm 0.02 \\
169.65 \pm 34.98 \\
189.28 \pm 37.68\end{array}$ & $\begin{array}{c}13.94 \pm 0.03 \\
1.78 \pm 0.02 \\
174.25 \pm 38.78 \\
193.01 \pm 37.96 \\
\end{array}$ & $\begin{array}{c}16.93 \pm 1.45 \\
6.25 \pm 1.33 \\
179.54 \pm 38.18 \\
198.31 \pm 30.46\end{array}$ \\
\hline
\end{tabular}

Comfort properties of the liners showed that leathers with high water vapor permeability and static water absorption characteristics could be one of the reasons to be used as a potential liner for the prosthetic leg users. Leather liners could absorb the sweat generated during the movements and help to evaporate the sweat which provides wear comfort and hygiene to prosthetic leg users.

\section{Mechanical Resistance of the Liners}

The mechanical resistance of the liners in terms of tensile and tear strength are given in Table 3. The tensile and tear strengths of the leathers were found higher than the synthetic liners. Although the lamination process with spandex fabric caused a decrease in tensile strength, no significant difference in tear strength values was observed.
Tear strength values of the gel and silicone liners were determined higher than the tensile strength values and the strengths of the gel and silicone liners were found considerably lower than those of the leathers.

In contrast to strength values of gel and silicone liners, the elongation at break (\%) values were found nearly 4 times higher than the leather liners. This is the expected result that generates because of the raw material of the liners. And the lamination of the leathers with spandex fabric was performed to improve the percentage of elongation at break values. And positive results were achieved (Table 3 ). The tensile and tear strength properties of the leathers were found adequate in accordance with UNIDO [17] acceptable leather qualities.

Table 3: Mechanical resistance of the liners

\begin{tabular}{lccc}
\hline & $\begin{array}{c}\text { Tensile strength (N/ } \\
\left.\mathrm{mm}^{2}\right)\end{array}$ & Elongation (\%) & $\begin{array}{c}\text { Double edge tear strength } \\
(\mathrm{N}) /(\mathrm{mm})\end{array}$ \\
\hline Silicone & $1.15 \pm 0.0$ & $325.7 \pm 0.0$ & $25.42 \pm 0.48$ \\
Gel liner with sock_blck & $0.96 \pm 0.0$ & $456.4 \pm 0.0$ & $6.98 \pm 0.0$ \\
Gel Liner with sock & $1.09 \pm 0.28$ & $350.94 \pm 61.24$ & $16.36 \pm 1.08$ \\
Gel Liner & $0.36 \pm 0.04$ & $500 \pm 0.0$ & $3.24 \pm 0.0$ \\
Stretched Leather & $17.51 \pm 0.25$ & $97.3 \pm 0.65$ & $68 \pm 0.06$ \\
Leather & $31.82 \pm 0.51$ & $80.4 \pm 3.47$ & $70.24 \pm 1.72$ \\
\hline
\end{tabular}

The mechanical results of the leather liners showed that the main advantage for the users is the long-term use of leather liners compared

to the gel and silicone liners due to their high mechanical properties.

Table 4: Rubbing fastness results of the liners

\begin{tabular}{lcccc}
\hline & \multicolumn{2}{c}{ Dry } & \multicolumn{2}{c}{ Wet } \\
& Felt & Material & Felt & Material \\
\hline Leather liners & 5 & 5 & $4 / 5$ & $4 / 5$ \\
Synthetic liners & 5 & 5 & 5 & 5 \\
\hline
\end{tabular}

Rubbing fastness values of the liners are shown in Table 4. The rubbing fastness values of synthetic and leather liners were found similar except from the leathers rubbed in wet condition.

\section{CONCLUSIONS}

In the study, leather liners as an alternative to synthetic liners were produced for the prosthetic leg users based on the properties of the synthetic liners (gel and silicone based) found in the market and following conclusions have been drawn:

a. Leather liners had considerably high water vapor permeability and static water absorption values compared to gel and silicone liners.

b. The high mechanical resistance of the leather liners provides a long-term use to the prosthetic leg users. 
c. Leather liners gain advantages over synthetic liners in terms of wear comfort, hygiene and long-term use and could be a perfect potential natural liner compared to synthetic liners.

d. To eliminate the discomfort feeling of the patients during the movements, leather liners could be produced as multilayer liners.

e. The findings of the study are important because new field of application for leather industry is found and the production of high performance leathers for the liners of the prosthetic users has a considerable potential needed to be strengthened by the cooperation of orthopedic device companies.

\section{Acknowledgements}

The authors would like to thank to Turkey Prime Ministry State Planning Organization (Project no: 2007 DPT 001). In addition we thank to Deva Orthopedics and Güvener Leather Company (Izmir, Turkey) for supplying synthetic liners and pickled domestic sheepskins.

\section{REFERENCES}

1. Hanspal, R.S., Fisher, K., Nieveen, R., Disabil Rehabil, 2003, 25, 22, 1278-1280, https://doi. org/10.1080/09638280310001603983.

2. Ghoseiri, K., Safari, M., J Rehabil Res Dev, 2014, 51, 6, 855-868, https://doi.org/10.1682/ JRRD.2013.06.0133.

3. Ghoseiri, K., Zheng, Y.P., Leung, A.K.L., Rahgozar, M., Aminian, G., Lee, T.H., Safari, M.R., Assist Technol, 2018, 30, 1, 16-23, https://doi.org/10.1080/10400435.2016.122 5850.

4. Klute, G.K., Rowe, G.I., Mamishev, A.V., Ledoux, W.R., Prosthetics and Orthotics International, 2007; 31, 3, 292 - 299, https:// doi.org/10.1080/03093640601042554.

5. Wernke, M.M., Schroeder, R.M., Kelley, C.T., Denune, J.A., Colvin, J.M., Journal of Prosthetics and Orthotics, 2015, 27, 134-139, https://doi.org/10.1097/ JPO.0000000000000070.

6. Webber, C.M., Davis, B.L., Journal of Biomechanics, 2015, 48,7,1294-1299, https:// doi.org/10.1016/j.jbiomech.2015.02.048.

7. Ghoseiri, K., Zheng, Y., Hing, L., Safari,
M., Leung, A., Prosthet Orthot Int, 2016, 40, 6, 751-755, https://doi. org/10.1177/0309364615588343.

8. Örk, N., Yiğit, Ü., Adıgüzel Zengin, A.C., Bitlisli, B.O., $8^{\text {th }}$ International Istanbul Conference on Evolution Technical Textile (ETT2018), 14-16 April 2018, İstanbul, Turkey, Proceeding of Abstracts, 2018, 140.

9. TS EN ISO 2418, Chemical, physical and mechanical and fastness tests, Sampling location, Turkish Standard Institute (TSE), Ankara, Turkey, 2006.

10.TS EN ISO 2419, Leather- Physical and mechanical tests- Sample preparation and conditioning, Turkish Standard Institute (TSE), Ankara, Turkey, 2006.

11. TS EN ISO 14268, Leather - Physical and mechanical tests - Determination of water vapor permeability, Turkish Standard Institute, (TSE), Ankara, Turkey, 2004.

12.TS 4123 EN ISO 2417, Leather - Physical and mechanical tests - Determination of the static absorption of water, Turkish Standard Institute, (TSE), Ankara, 2005.

13.TS EN ISO 3376, Leather - Physical and mechanical tests - Determination of tensile strength and percentage extension, Turkish Standard Institute, (TSE), Ankara, Turkey, 2012.

14. TS EN ISO 3377-2, Leather - Physical and mechanical tests - Determination of tear load - Part 2: Double edge tear, Turkish Standard Institute, (TSE), Ankara, Turkey, 2016.

15. TS 4117 EN ISO 2589, Leather - Physical and mechanical tests - Determination of thickness, Turkish Standard Institute, (TSE), Ankara, Turkey, 2006.

16.TS EN ISO 11640, Leather-tests for colour fastness-Colour fastness to cycles of to-andfro rubbing, Turkish Standard Institute, (TSE), Ankara, Turkey, 2013.

17.UNIDO, Acceptable Quality Standards in the Leather and Footwear Industry. Vienna, Austria: United Nations Industrial Development Organization, 1996.

(C) 2018 by the author(s). Published by INCDTPICPI, Bucharest, RO. This is an open access article distributed under the terms and conditions of the Creative Commons Attribution license (http:// creativecommons.org/licenses/by/4.0/). 